\title{
Biochemical and Molecular Mechanisms Involved in Monogenic Resistance Responses to Tomato Powdery Mildew
}

\author{
Chengwei Li, ${ }^{1}$ Guusje Bonnema, ${ }^{1}$ Daidi Che, ${ }^{2,3}$ Lin Dong, ${ }^{1}$ Pim Lindhout, ${ }^{1}$ Richard Visser, ${ }^{1}$ and \\ Yuling Bai ${ }^{1}$ \\ ${ }^{1}$ Laboratory of Plant Breeding, Wageningen University, PO Box 386, 6700 AJ Wageningen, The Netherlands; ${ }^{2}$ Horticulture \\ College of Northeast Agricultural University, Haerbin 150030, China; ${ }^{3}$ Northeast Forestry University, Haerbin 150040 , China
}

Submitted 4 December 2006. Accepted 9 April 2007.

\begin{abstract}
The monogenic genes $0 l-1, o l-2$, and $O l-4$ confer resistance to tomato powdery mildew Oidium neolycopersici via different mechanisms. The biochemical mechanisms involved in these monogenic resistances were studied by monitoring through time the association of $\mathrm{H}_{2} \mathrm{O}_{2}$ and callose accumulation with hypersensitive response (HR) and papilla formation. Our results showed that $\mathrm{H}_{2} \mathrm{O}_{2}$ and callose accumulation are coupled with both $\mathrm{Ol}-1$ - and $\mathrm{Ol}$-4-mediated HR-associated resistance as well as with the ol-2-mediated papillaeassociated resistance. Further, the transcriptomal changes related to these monogenic resistances were studied by using cDNA-amplification fragment length polymorphism. The expression profiling clarified that $81 \%$ of DE-TDF (differentially expressed transcript-derived fragments) were upregulated upon inoculation with $O$. neolycopersici in both the compatible and Ol-1-mediated incompatible interactions, though with a difference in expression timing. Of these DE-TDF, more than $70 \%$ were not detected in the $\mathrm{Ol}$ 4-mediated resistance, while $58 \%$ were expressed in the ol2-mediated resistance, generally at later timepoints. Sequence information suggested that most of these DE-TDF are related to genes involved in either basal defense or establishment of compatibility. In addition, DE-TDF (19\%) specifically expressed in different incompatible interactions were identified. Expression patterns of some DE-TDF and marker gene GluB suggested that papillae-associated resistance exploits a different defense pathway from that of HRassociated resistance.
\end{abstract}

Plants encounter microbes constantly, and the ability to detect pathogens and mount defense responses has been a precondition for their developmental success (Chisholm et al. 2006; Nurnberger and Kemmerlich 2006). A two-layered innate immune system for defense against pathogens has been devel-

C. Li and G. Bonnema contributed equally to this study.

Corresponding author: Y. Bai; Telephone: +31 317 477284; Fax: +31 317 483457; E-mail: bai.yuling@wur.nl

Current address for C. Li: Department of Life Sciences, Shangqiu Normal University, Shangqiu 476000, China.

Current address for P. Lindhout: De Ruiter Seeds, PO Box 1050, 2600 BB, Bergschenhoek, The Netherlands.

* The $\boldsymbol{e}$-Xtra logo stands for "electronic extra" and indicates that Figures 1,2 , and 3 appear in color online. oped in plants. The first line of defense is primary innate immunity defined by a set of membrane-resident pattern recognition receptors (PRR) that recognize pathogen-associated molecular patterns (PAMP), which is also known as PAMP-triggered immunity (PTI) (Chisholm et al. 2006). Recognition of PAMP leads to activation of a range of basal defense mechanisms, including induction of pathogen-responsive proteins, production of reactive oxygen species (ROS), and deposition of callose at the penetration site (Nurnberger et al. 2004). However, pathogenic microbes have evolved a measure to suppress the PTI, which involves interfering with the recognition of PRR and PAMP through excretion of elicitors (Chisholm et al. 2006). To combat pathogens that have acquired the ability to overcome the basal defense, plants have developed a second line of defense or secondary innate immunity, which is a more specialized mechanism and is also referred to as effectors-triggered immunity (ETI) (Chisholm et al. 2006). ETI is initiated by direct or indirect recognition between resistance $(\mathrm{R})$ proteins and microbial effectors and is $R$ gene-specific resistance, which fits the gene-for-gene model (Flor 1971). The PRR and R proteintriggered defense responses are very similar; for example, ROS accumulation and induction of pathogen-responsive proteins are also linked to ETI, although the defense responses are enhanced in timing and amplitude in ETI compared with PTI (Tao et al. 2003). How plants integrate signals of these two receptor classes remains elusive (Nurnberger et al. 2006). Very recently, it was demonstrated in barley that MLA receptors ( $R$ protein receptors) target directly the transcriptional machinery of PAMP-triggered basal defense, providing a crosstalk between PTI and ETI (Shen et al. 2007).

Hypersensitive response (HR), an active and rapid death of the attacked (epidermal) cells, is well-studied as a defense response to restrict the development of a pathogen. Generally, the pair association of plant $\mathrm{R}$ proteins and microbial effectors results in HR, which was known to be the central component of plant ETI (Chisholm et al. 2006). To trigger $\mathrm{HR}, \mathrm{H}_{2} \mathrm{O}_{2}$ is supposed to function as a signaling molecule in programmed cell death (Hückelhoven and Kogel 1998; Lamb and Dixon 1997). Induction of pathogen-related (PR) proteins represents one of the basal defense mechanisms, and different families of PR proteins have been identified in most plant species studied (Lo et al. 1999). Some of these $P R$ genes are specific to the well-defined defense pathways activated by salicylic acid (SA), jasmonic acid (JA), or ethylene (ET) (Smart et al. 2003). Besides $P R$ genes, some specific genes are known to be required for disease resistance in plants, such as SGT1 in R proteintriggered defense signaling (Muskett and Parker 2003) and 
PEN1 (homologous to ROR2) being essential for mlo-based papillae-mediated resistance (Consonni et al. 2006).

Our research aims to study the interaction of tomato with tomato powdery mildew, a serious disease caused by the biotrophic fungus Oidium neolycopersici. We have identified and mapped several monogenic genes ( $\mathrm{Ol}$ genes) for resistance to O. neolycopersici (Bai et al. 2004, 2005; Ricciardi et al. 2007). The race-specificity and resistance mechanisms associated with the $\mathrm{Ol}$ genes have been investigated using near-isogenic lines (NIL) (Bai et al. 2005). The dominant resistance genes (Ol-1, Ol-3, Ol-4, Ol-5, and $\mathrm{Ol}-6)$ confer race-specific resistance by hampering the fungal growth via HR of the host epidermal cells, while the recessive gene ol-2 confers resistance via papilla formation (Bai et al. 2005). Aiming to study genes involved in defense responses of tomato to $O$. neolycopersici, we have compared the transcript profiles of the compatible interaction with the incompatible interaction mediated by the gene $O l-1$ (Li et al. 2006). Transcript derived fragments have been identified that are differentially expressed (DE-TDF) upon fungal challenge. A similar set of DE-TDF was activated with a large proportion of the DE-TDF earlier expressed in incompatible versus compatible interactions, which is in agreement with the Arabidopsis and Pseudomonas syringae interaction as described by Tao and associates (2003), suggesting a link between PTI and ETI.

In the present study, we further investigated the expression pattern of the DE-TDF involved in tomato responses to $O$. neolycopersici in NIL bearing the dominant resistance genes $\mathrm{Ol}-\mathrm{I}$ and $\mathrm{Ol}-4$ and in one $\mathrm{F}_{3}$ line that contains the recessive resistance gene $o l-2$ (Bai et al. 2005). These monogenic $O l$ genes are associated with different resistance mechanisms (HR or papilla formation) and arrest fungal growth at different stages of the infection processes. In this study, the progress of both HR and papilla formation was monitored in time and their association with $\mathrm{H}_{2} \mathrm{O}_{2}$ and callose accumulation was studied.

\section{RESULTS}

\section{Compatible and incompatible interactions between tomato and $O$. neolycopersici.}

Previously, we studied defense responses triggered by $O$. neolycopersici in NIL-Ol-1, NIL-Ol-4, and F3-ol-2 at $65 \mathrm{~h}$ postinoculation (hpi) and observed HR and papilla formation, depending on the genotypes. In this study, we focused on earlier timepoints to monitor the development and progress in HR and papilla formation.
The fungal development was microscopically evaluated at 18 , 24, and 41 hpi (Table 1). Compared with susceptible Solanum lycopersicum cv. Moneymaker (S-MM), NIL-Ol-1 showed similar fungal growth patterns as defined by the number of primary haustoria, hyphae, and secondary appressoria and haustoria per infection unit (IU) (Table 1). NIL-Ol-4, however, showed a significantly lower number of primary haustoria than S-MM and NIL-Ol-1 at $41 \mathrm{hpi}$, and fungal growth was largely arrested in the first attacked epidermal cells (cells attacked by primary appressoria), as judged by the near absence of secondary appressoria and haustoria. In F3-ol-2, less than $10 \%$ of the IU formed primary haustoria and hypha elongation was hardly observed.

In S-MM and F3-ol-2, almost no first-attacked epidermal cells became necrotic (HR). In contrast, HR cells were detected in epidermal cells of NIL-Ol-1 and NIL-Ol-4 (Table 1), in which HR was often associated with shriveled haustoria. In both NIL, HR occurred after the formation of haustoria, although very few cases were found in NIL-Ol-4, in which HR was visible before haustorium formation. In NIL-Ol-1, HR developed later with a lower frequency than in NIL-Ol-4. Further fungal growth was completely blocked in NIL-Ol-4 by the first-attacked epidermal cell undergoing HR, while in NIL-Ol1 , HR was not $100 \%$ effective to stop further fungal growth (Table 1; Fig. 1). F3-ol-2 was characterized by papilla formation beneath the primary appressoria (Table 1; Fig. 1). No papillae were associated with haustorium formation at $18 \mathrm{hpi}$, but less than $10 \%$ papillae were formed around the haustorial neck at 24 and 41 hpi (Fig. 1). Our previous data (Bai et al. 2005) showed that, in the same line at $65 \mathrm{hpi}, 40 \%$ of the papillae were associated with primary haustoria, suggesting that papillae were penetrated by the formation of primary haustoria. In summary, the defense response in NIL-Ol-4 and F3-ol-2 seems to become effective earlier than in NIL-Ol-1. Fungal-growth arrest coincided with papilla formation in F3-ol-2, with a fast $\mathrm{HR}$ reaction (at primary haustorium stage) in NIL-Ol-4 and with a slow HR response (at both primary and secondary haustorium stages) in NIL-Ol-1 (Fig. 1).

Our previous data (Bai et al. 2005) showed that the germination ratio (percentage of the germinated spores) in F3-ol-2 was lower than in MM and other NIL containing different dominant resistance genes to $O$. neolycopersici. In those experiments, leaves were stained in tubes, which may result in the washing away of spores. To verify whether fungal germination was really inhibited in F3-ol-2, the leaf segments in this experiment were stained in petri dishes to prevent washing away of spores and to

Table 1. Development of Oidium neolycopersici on tomato lines Solanum lycopersicum cv. Moneymaker (S-MM) and near-isogenic lines (NIL) bearing the dominant resistance genes $\mathrm{Ol}-1$ and $\mathrm{Ol}-4$ (NIL-Ol-1 and NIL-Ol-4) and in one $\mathrm{F}_{3}$ line (F3-ol-2) ${ }^{\mathrm{a}}$

\begin{tabular}{|c|c|c|c|c|c|c|c|}
\hline \multirow[b]{2}{*}{ Genotype } & \multirow[b]{2}{*}{ Timepoint } & \multirow{2}{*}{$\begin{array}{c}\text { Primary } \\
\text { Haustorium (\%) }\end{array}$} & \multirow[b]{2}{*}{$\operatorname{HR}^{\mathrm{b}}(\%)$} & \multirow[b]{2}{*}{ Papillae $^{c}(\%)$} & \multirow[b]{2}{*}{ Hyphae } & \multicolumn{2}{|c|}{ Secondary } \\
\hline & & & & & & Appressorium & Haustorium \\
\hline \multirow[t]{3}{*}{ S-MM } & 18 & 62 & 2 & 0 & 0.5 & 0.0 & 0.0 \\
\hline & 24 & 66 & 1 & 2 & 1.1 & 0.2 & 0.1 \\
\hline & 41 & 80 & 1 & 2 & 2.0 & 1.2 & 0.5 \\
\hline \multirow[t]{3}{*}{ NIL-Ol-1 } & 18 & 67 & 0 & 1 & 0.5 & 0.1 & 0.0 \\
\hline & 24 & 71 & 4 & 6 & 0.9 & 0.2 & 0.2 \\
\hline & 41 & 91 & 26 & 4 & 2.4 & 1.5 & 0.6 \\
\hline \multirow[t]{3}{*}{ F3-ol-2 } & 18 & 3 & 0 & 33 & 0.0 & 0.0 & 0.0 \\
\hline & 24 & 9 & 0 & 57 & 0.0 & 0.0 & 0.0 \\
\hline & 41 & 7 & 0 & 85 & 0.2 & 0.1 & 0.0 \\
\hline \multirow[t]{3}{*}{ NIL-Ol-4 } & 18 & 52 & 16 & 0 & 0.3 & 0.0 & 0.0 \\
\hline & 24 & 64 & 52 & 0 & 0.5 & 0.1 & 0.0 \\
\hline & 41 & 57 & 73 & 0 & 0.6 & 0.2 & 0.1 \\
\hline
\end{tabular}

${ }^{a}$ At the indicated timepoints 18, 24, and 41 hpi (hours postinoculation), leaf segments were microscopically analyzed. Numbers represent 240 infection units (IU) of 12 leaf segments ( $20 \mathrm{IU}$ per leaf segment) from three different staining methods. Values represent percent or number per IU.

${ }^{\mathrm{b}}$ Hypersensitive response (HR) in epidermal cells where primary appressoria (and haustoria) formed.

${ }^{\mathrm{c}}$ Papillae at the primary interaction site where fungus tries to penetrate. 
get unbiased germination data. The germination ratio at $41 \mathrm{hpi}$ was $28 \%$ for S-MM, $13 \%$ for NIL-Ol-1, and $10 \%$ for F3-ol-2 and NIL-Ol-4. Clearly, the spore germination ratio was not lower in F3-ol-2 as compared with the other two NIL. However, the data did show that the spore germination ratio in S-MM was significantly higher than in all three resistant genotypes. To learn whether the germination ratio plays a role in resistances to $O$. neolycopersici, it will be necessary to record spore germination ratios at more timepoints and with different inoculation methods (spray and contact inoculation) (Bai et al. 2005).

\section{$\mathrm{H}_{2} \mathrm{O}_{2}$ accumulation}

\section{in both compatible and incompatible interactions.}

$\mathrm{H}_{2} \mathrm{O}_{2}$ from the oxidative burst has been shown to drive several plant defense responses (Hückelhoven and Kogel 1998; Lamb and Dixon 1997). To investigate whether $\mathrm{H}_{2} \mathrm{O}_{2}$ is involved in the interaction between tomato and $O$. neolycopersici, DAB (diaminobenzidine) staining was performed to show histochemical localization of $\mathrm{H}_{2} \mathrm{O}_{2}$. Upon inoculation with $O$. neolycopersici, $\mathrm{H}_{2} \mathrm{O}_{2}$ accumulation in epidermal cells was almost absent in S-MM and F3-ol-2 (Fig. 2A), while in NIL-Ol-1 and NIL-Ol-4, $\mathrm{H}_{2} \mathrm{O}_{2}$ accumulation was detected always in cells that underwent HR (Figs. 2A and 3A). NIL-Ol-4 had a fast HR compared with NIL-Ol-1; similarly, NIL-Ol-4 also showed earlier (at $18 \mathrm{hpi}$ ) $\mathrm{H}_{2} \mathrm{O}_{2}$ generation in attacked cells than did NIL-Ol-1 (at 24 hpi). In F3-ol-2, more than $50 \%$ of the first interaction sites (where appressoria were located) showed $\mathrm{H}_{2} \mathrm{O}_{2}$ accumulation, compared with about $15 \%$ in S-MM and other NIL in which no obvious papilla formation was observed (Figs. 2B and 3B). One exception is NIL-Ol-1 in which, at 24 hpi, $\mathrm{H}_{2} \mathrm{O}_{2}$ accumulation was detected at $40 \%$ of the interaction sites of non-HR cells with haustoria. At 41 hpi in contrast, $\mathrm{H}_{2} \mathrm{O}_{2}$ accumulation was mainly detected in HR cells in this line, which suggested that $\mathrm{H}_{2} \mathrm{O}_{2}$ generation precedes HR. In summary, both HR and papilla formation in tomato attacked by $O$. neolycopersici are associated with $\mathrm{H}_{2} \mathrm{O}_{2}$ accumulation.

\section{Callose accumulation}

in both compatible and incompatible interactions.

Upon inoculation with $O$. neolycopersici, callose deposition was observed at the interaction sites and also around the cell wall depending on genotypes and timepoints. The callose deposition did not extend along the cell wall in S-MM and F3-ol-2, but did so in NIL-Ol-1 and NIL-Ol-4 (Figs. 2C and 3C). Compared with NIL-Ol-1, this callose deposition in NIL-Ol-4 was faster and with a higher percentage. At 41 hpi, callose deposition was associated with HR cells, while at earlier timepoints, callose was present around the wall of non-HR cells, indicating

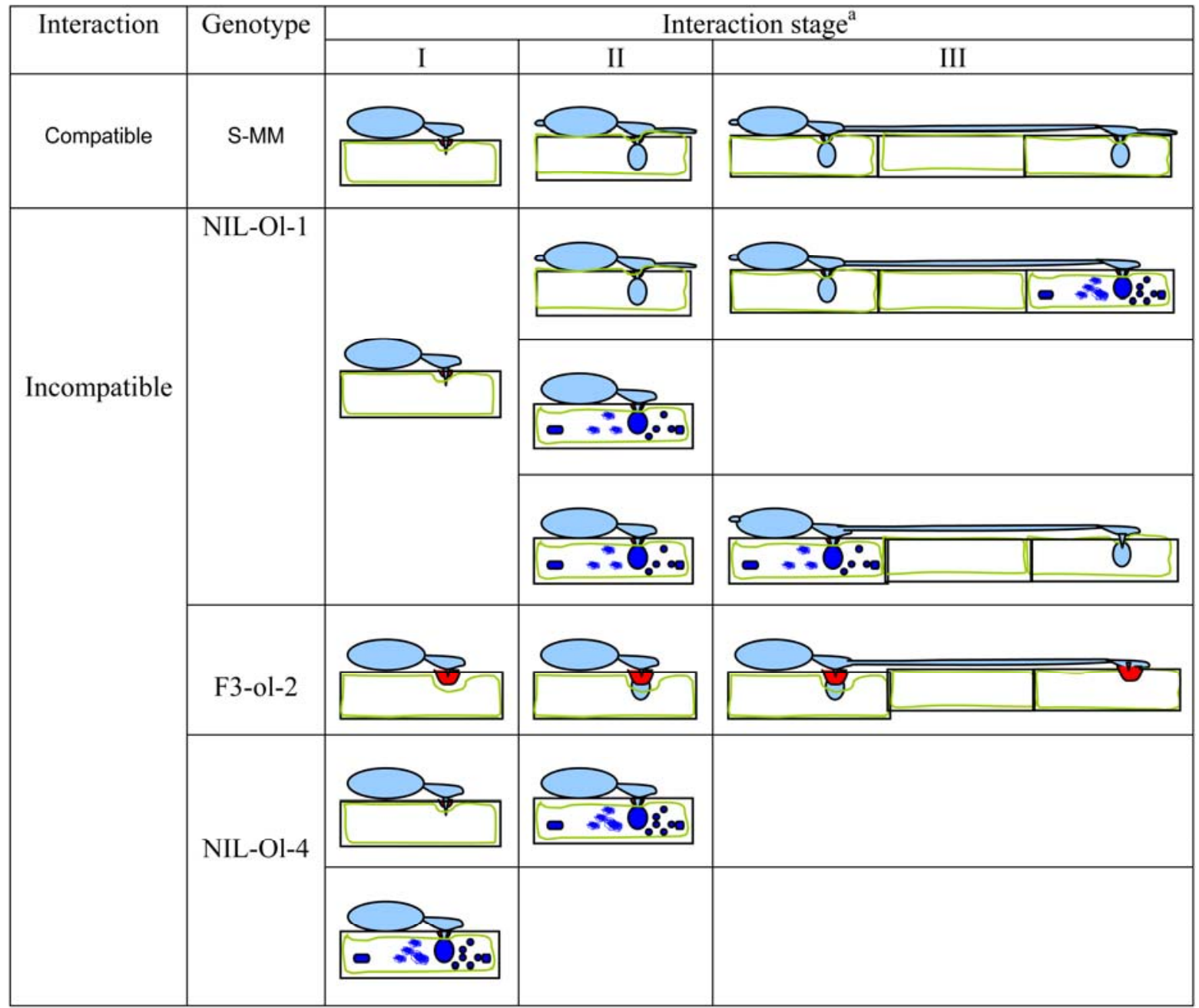

Fig. 1. Diagram of the main interaction stages in compatible and incompatible interactions, in which resistant tomato plants establish defense barriers to

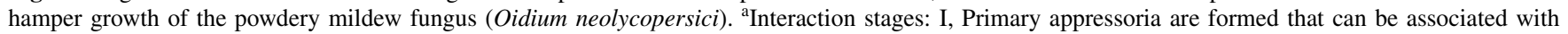
papilla formation (cell-wall deposition at the penetration sites), as in F3-ol-2. The attacked host cells either stay alive or undergo necrotic responses (HR; indicated by cells with particles) as in NIL-Ol-4; II, Primary haustoria are formed in epidermal cells that can subsequently undergo HR, as in NIL-Ol-4 and NIL-Ol-1; III, Secondary haustoria are formed in epidermal cells and can trigger HR in the attacked host cells, as in NIL-Ol-1. Secondary appressoria are formed that are coupled with papilla formation in F3-ol-2. 
that callose deposition occurred before visible HR. Rarely, NILOl-4 showed systemic callose deposition in mesophyll cells (Fig. 3D) that were located underneath the attacked epidermal cells with callose accumulation (Fig. 3C). This was never observed in other genotypes.

In F3-ol-2, callose deposition at the interaction sites (Fig. 3E) was associated with papilla formation, indicating that papillae in F3-ol-2 are formed with callose-containing material. Although papilla formation was rare in S-MM and NIL-Ol-1, at 41 hpi, more than $50 \%$ of the first interaction sites in these two lines were associated with callose deposition (Figs. 2D and 3F) at the penetration sites of non-HR cells with haustoria. The callose deposit at penetration sites in F3-ol-2 (Fig. 3E) was more abundant (as indicated by the intensity of the fluorescent signal) than that in other genotypes (Fig. 3F). In general, callose deposition was not only associated with papilla formation and HR but also detected at interaction sites at which successful fungal penetration occurred.
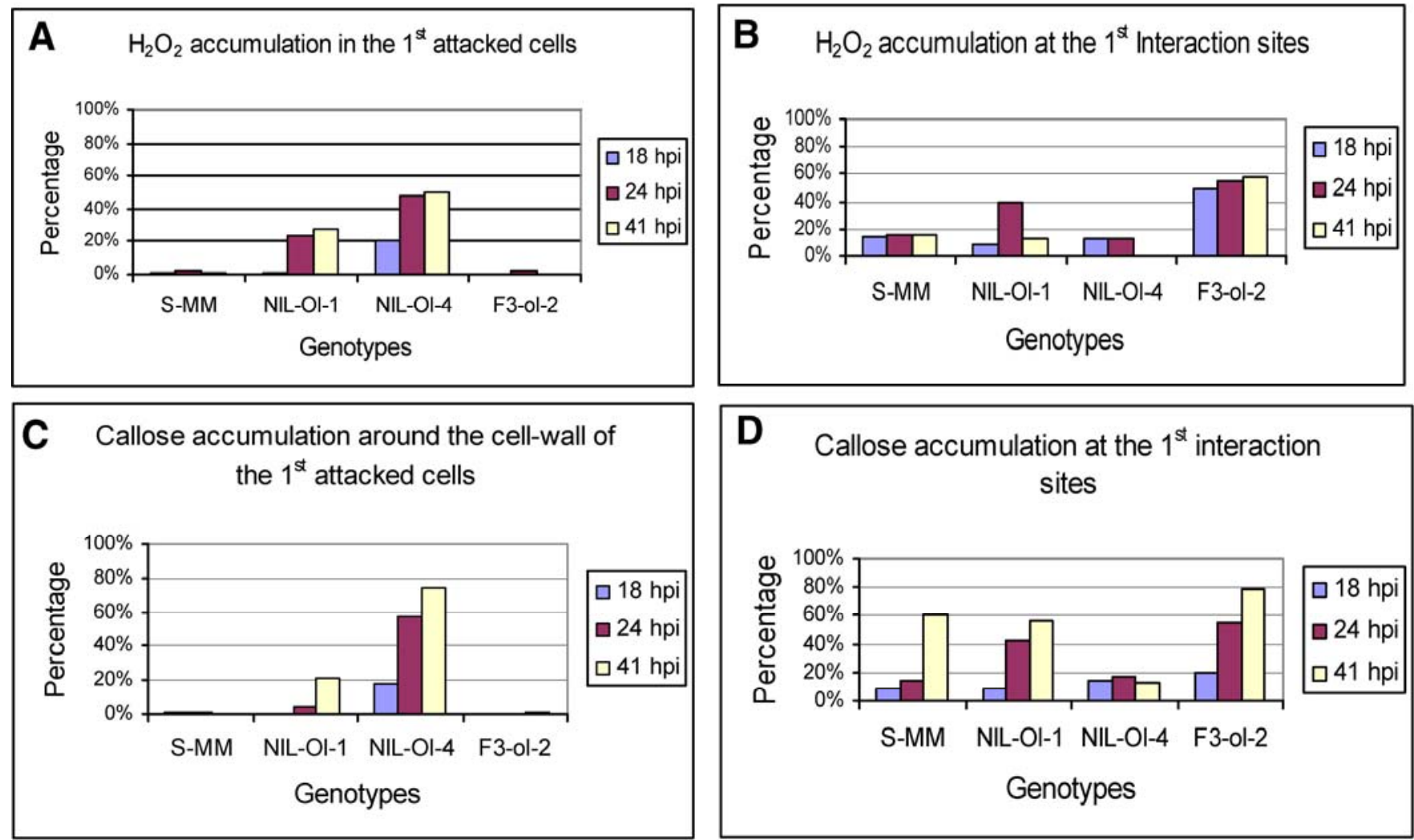

Fig. 2. $\mathrm{H}_{2} \mathrm{O}_{2}$ and callose accumulation in compatible and incompatible interactions. At the indicated timepoints 18,24 , and $41 \mathrm{~h}$ postinoculation, leaf segments were microscopically analyzed for positive $\mathrm{H}_{2} \mathrm{O}_{2}$ and callose staining. Each column was calculated from 80 infection units (IUs) of four leaf segments. The first interaction site was defined as the place where a primary appressorium was formed at the epidermal cell that was named the first attacked epidermal cell. A and B, Incidence of $\mathrm{H}_{2} \mathrm{O}_{2}$ staining in the first attacked epidermal cells showing a hypersensitive response and at the first interaction sites, respectively. $\mathbf{C}$ and $\mathbf{D}$, Incidence of callose deposition around the cell wall of the first attacked epidermal cells and at the first interaction sites, respectively.
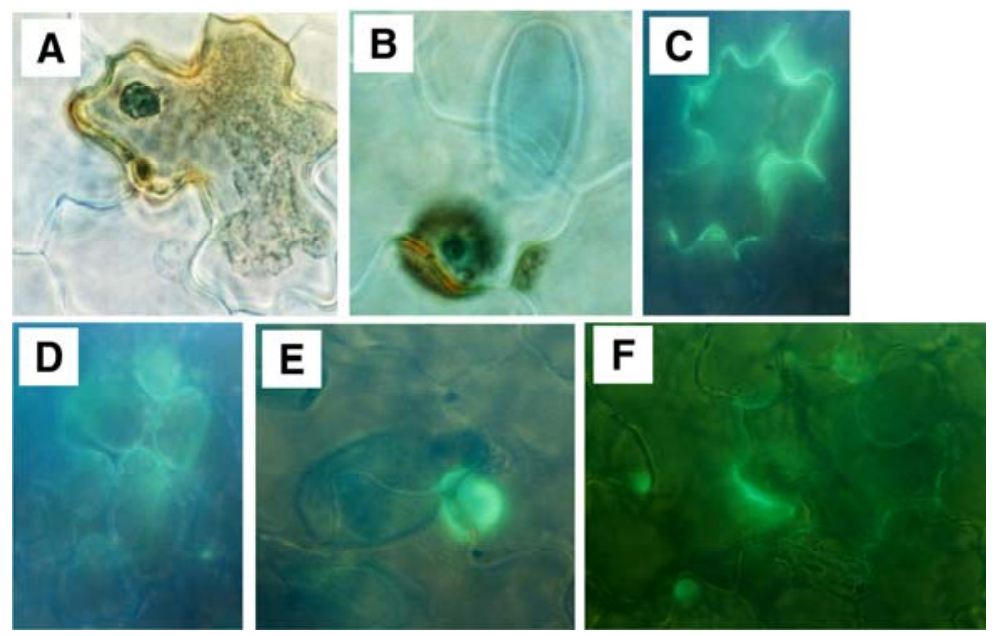

Fig. 3. Accumulation of $\mathrm{H}_{2} \mathrm{O}_{2}$ and callose in compatible and incompatible interactions. $\mathbf{A}, \mathrm{H}_{2} \mathrm{O}_{2}$ accumulation in the attacked cell undergoing hypsersensitive response (in NIL-Ol-4 at $24 \mathrm{~h}$ postinoculation [hpi]). $\mathbf{B}, \mathrm{H}_{2} \mathrm{O}_{2}$ accumulation at the penetration site (in F3-ol-2 at 18 hpi). C, Callose accumulation around the attacked cell wall (in NIL-Ol-4 at 41 hpi). D, Systemic callose deposition in the underlying mesophyll cells (in NIL-Ol-4 at 41 hpi). E and F, Callose deposition at one or more penetration sites (in F3-ol-2 at $41 \mathrm{hpi}$ and in S-MM at $41 \mathrm{hpi}$, respectively). 


\section{DE-TDF identified in cDNA-amplification fragment length} polymorphism (AFLP) analyses.

To elucidate the transcriptional responses in the interaction of tomato with $O$. neolycopersici, gene expression profiles in compatible and incompatible interactions were monitored using cDNA-AFLP on S-MM, NIL-Ol-1, F3-ol-2, and NILOl-4. A total of 69 primer combinations were selected that displayed DE-TDF between fungal-inoculated and mockinoculated plants ( $\mathrm{Li}$ et al. 2006). These 69 primer combinations generated about 3,000 bands, of which 112 DE-TDF were up-regulated in the inoculated plants as compared with mock-inoculated plants (Fig. 4, classes I to III). Of the 112 DE-TDF, $91(81 \%)$ were present in both compatible and incompatible interactions (Class I and II) and 21 (19\%) were detected specifically in incompatible interactions of resistant genotypes (Class III). Among the Class I and II DE-TDF (91), all were up-regulated in both S-MM and NIL-Ol-1 with similar expression patterns, while 53 (Class I and II-b) were also up-regulated in F3-ol-2 and 25 (Class I and II-c) in NILOl-4. Compared with NIL-Ol-1, most of these DE-TDF displayed later expression timing in F3-ol-2 and NIL-Ol-4. In addition, nine DE-TDF (Class II-c) showed no altered expression in F3-ol-2. Class III DE-TDF, which were up-regulated only in the resistant genotypes, illustrated that different genotypes expressed specific DE-TDF.

In addition to the DE-TDF that were up-regulated in inoculated plants compared with mock-inoculated plants, $29 \mathrm{TDF}$ (Class IV) were constitutively expressed, but not in all geno-

\begin{tabular}{|c|c|c|c|c|c|c|}
\hline \multirow[t]{2}{*}{ Class } & \multirow{2}{*}{$\begin{array}{l}\text { Number of } \\
\text { DE-TDF }\end{array}$} & \multirow[t]{2}{*}{ Description of expression pattern } & S-MM & NIL-OI-1 & F3-ol-2 & NIL-OI-4 \\
\hline & & & ${ }^{a} \mathrm{P} 13579$ & P13579 & P13579 & P13579 \\
\hline $\mathrm{I}$ & 16 & $\begin{array}{l}\text { Up regulated in all genotypes, most } \\
\text { later in F3- ol-2 and NIL-Ol-4 }\end{array}$ & & & & \\
\hline II & 75 & $\begin{array}{l}\text { Up regulated in S-MM and at least } \\
\text { in one of the resistant genotypes }\end{array}$ & & & & \\
\hline $\mathrm{II}-\mathrm{a}$ & 29 & Up regulated in S-MM and NIL-Ol-1 & & & & \\
\hline II-b & 37 & $\begin{array}{l}\text { Up regulated in S-MM, NIL-Ol-1 and } \\
\text { F3-ol-2, but most are later in F3-ol-2 }\end{array}$ & & - & & $\longleftarrow$ \\
\hline II-C & 9 & $\begin{array}{l}\text { Up regulated in all genotypes with } \\
\text { similar expression timing. Most } \\
\text { weakly expressed constitutively in } \\
\text { F3-ol-2 }\end{array}$ & & & & \\
\hline IIII & 21 & $\begin{array}{l}\text { Up regulated in the resistant } \\
\text { genotypes but not in S-MM }\end{array}$ & & & & \\
\hline III-a & 5 & Up regulated only in NIL-OI-1 & & & & 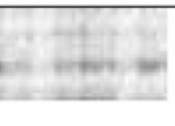 \\
\hline III-b & 9 & Up regulated only in F3-ol-2 & +2 & $\bar{x}$ & $=0$ & $\longleftarrow$ \\
\hline III-c & 5 & Up regulated only in NIL-OI-4 & & & & 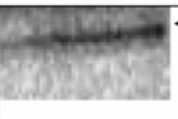 \\
\hline III-d & 2 & $\begin{array}{l}\text { Up regulated in NIL-OI-1 and NIL- } \\
\text { OI-4 }\end{array}$ & & & & Exontivel \\
\hline IV & 29 & $\begin{array}{l}\text { Polymorphic bands associated with } \\
\text { resistant genotypes }\end{array}$ & & & & \\
\hline Total & 141 & & & & & \\
\hline
\end{tabular}

Fig. 4. Different expression classes of the DE-TDF (differentially expressed transcript derived fragments) in the cDNA amplification fragment length polymorphism analysis. Susceptible genotype (S-MM) and resistant genotypes: NIL-Ol-1, F3-ol-2 and NIL-Ol-4. ${ }^{\mathrm{a}} \mathrm{P}$ represents the pooled mock-inoculated samples harvested at 1,3,5,7, and 9 days postinoculation (dpi); inoculated samples are represented by numbers referring to sampling at 1,3,5, 7, and 9 dpi; Arrows indicate the target TDF. 
types. These class IV TDF may represent candidate genes for the resistance genes $\mathrm{Ol}-1, \mathrm{ol}-2$, and $\mathrm{Ol}-4$, genes regulated or required by these resistance loci, or genes that have been introgressed into the NIL due to their linkage with the target $O l$ genes. One TDF, M18E41-220 (Appendix 1, no. 36), specifically expressed in NIL-Ol-4 is indeed mapped in silico in the chromosomal region in which $\mathrm{Ol}-4$ is located.

\section{Identities of DE-TDF.}

In total, sequences of $50 \mathrm{DE}-\mathrm{TDF}$ were obtained and blasted against The Institute for Genomic Research (TIGR) tomato and Arabidopsis tentative consensus (TC) databases. On the basis of the BLAST results, the DE-TDF were classified into several groups (Table 2), as described by $\mathrm{Li}$ and associates (2006). In total, 36 DE-TDF had homology to expressed genes (Appendix 1) and 14 had no good matches (E value $>5 \mathrm{e}-2)$ in the databases. Although none of the DE-TDF showed homology in the fungal database, these 14 DE-TDF with no good matches can be potentially pathogen-derived, due to the fact that the plant-pathogenic fungi are underrepresented in these databases. Further hybridization of these DE-TDF to both tomato and fungal genomic DNA is needed to verify the identity of these 14 TDF.

As summarized in Table 2, the sequenced Class I and II DETDF (induced in both S-MM and resistant genotypes) either showed homology to expressed genes with unknown function or to genes that are mostly involved in known defense responses (Group A) and in protein synthesis (Group D). The transcripts of class III DE-TDF, which were specific to one or more incompatible interactions, were distributed into different functional groups, including signal transduction (B), regulation (C), and photosynthesis related (E). In addition, several interesting class IV TDF displaying constitutive expression patterns in resistant genotypes were sequenced. These TDF were homologous to transcripts involved in defense responses (Group A) and signal transduction (Group B) or had unknown functions (Group H).

\section{Reverse transcription-polymerase chain reaction (RT-PCR) for some signaling and resistance pathway genes.}

In order to clarify the defense pathways related to slow HR, fast HR, and papilla formation, RT-PCR was conducted to monitor the expression patterns of some known defense genes or tomato homologs of genes that affect resistance or susceptibility in other pathosystems (Table 3). Upon inoculation, expression of the LeSGT1 and LeROR2 genes was not altered in any of the four interactions (Fig. 5). The expression of the $P R$ 1 and $G l u B$ genes was up-regulated in S-MM and the two NIL (Fig. 5). The expression of the GluB gene in NIL-Ol-4 occurred earlier compared with that in S-MM and NIL-Ol-1, while in NIL-Ol-4, expression of $P R-1$ was up-regulated at 3 and 9 days postinoculation (dpi) and down-regulated at 5 and 7 dpi. In the F3-ol-2 line, the GluB gene showed nonaltered expression and the $P R-1$ gene showed late upregulation at 9 dpi. The expression pattern of $P R-1$ and $G l u B$ genes was further confirmed with protein profiles (data not shown) obtained from the intercellular fluid of tomato leaves infected with $O$. neolycopersici. As GluB and PR-1 are downstream components of different signaling pathways, the nonaltered expression or late upregulation of these two genes in F3-ol-2 indicated that the resistance mechanism mediated by the recessive gene ol-2 is

Table 2. Functional groups of the 50 sequenced differentially expressed transcript derived fragments (DE-TDF), based on the BLAST results against the The Institute for Genomic Research tentative consensus database

\begin{tabular}{|c|c|c|c|c|c|}
\hline \multirow[b]{2}{*}{ Blast results of DE-TDF sequences } & \multirow[b]{2}{*}{ Group } & \multirow[b]{2}{*}{ Total no. } & \multicolumn{3}{|c|}{ DE-TDF } \\
\hline & & & Class I and II & Class III & Class IV \\
\hline \multicolumn{6}{|c|}{ With functional information from plant expressed sequence tag (EST) databases } \\
\hline $\begin{array}{l}\text { Known defense responses (secondary metabolites synth } \\
\text { associated, oxidative burst etc.) }\end{array}$ & A & 8 & 7 & 0 & 1 \\
\hline Signal transduction (GTP-binding protein, kinases etc) & $\mathrm{B}$ & 6 & 2 & 2 & 2 \\
\hline Regulation (transcription factor, heat shock protein etc) & $\mathrm{C}$ & 5 & 3 & 2 & 0 \\
\hline Ubiquination pathway and protein synthesis related & $\mathrm{D}$ & 5 & 5 & 0 & 0 \\
\hline Photosynthesis, photorespiration and respiration & $\mathrm{E}$ & 2 & 0 & 2 & 0 \\
\hline Other $^{\mathrm{a}}$ & $\mathrm{F}$ & 0 & 0 & 0 & 0 \\
\hline \multicolumn{6}{|l|}{ No functional information from plant EST databases } \\
\hline Pathogen derived ${ }^{\mathrm{b}}$ & G & 0 & 0 & 0 & 0 \\
\hline Unknown $^{\mathrm{c}}$ & $\mathrm{H}$ & 10 & 5 & 1 & 4 \\
\hline No (good) hits ${ }^{\mathrm{d}}$ & $\mathrm{I}$ & 14 & 14 & 0 & 0 \\
\hline Total & & 50 & 36 & 7 & 7 \\
\hline
\end{tabular}

Table 3. Sequences of primer pairs used in reverse transcription-polymerase chain reaction (RT-PCR) analyses with their annealing temperature and length of PCR products

\begin{tabular}{|c|c|c|c|c|}
\hline \multirow[b]{2}{*}{ Primer name } & \multirow[b]{2}{*}{ Primer sequences $^{\mathrm{a}}$} & \multirow[b]{2}{*}{ Annealing Temperature $\left({ }^{\circ} \mathrm{C}\right)$} & \multicolumn{2}{|c|}{ PCR product length (bp) } \\
\hline & & & Genomic DNA & cDNA \\
\hline LeSGT1 & $\begin{array}{l}\text { F: GGAGTTCCTCTCCATCACCA } \\
\text { R: CCACCGACAGATTAGGCAAT }\end{array}$ & 55 & 520 & 400 \\
\hline LeROR2 & $\begin{array}{l}\text { F: CTGGTTGTGGACCTGGAAGT } \\
\text { R: CTGAGCACCACCTCTGACAA }\end{array}$ & 60 & 1000 & 420 \\
\hline PR1 & $\begin{array}{l}\text { F: TCTTGTGAGGCCCAAAATTC } \\
\text { R: GGATATCAATCCGATCCCACT }\end{array}$ & 53 & 500 & 500 \\
\hline GluB & $\begin{array}{l}\text { F: TGGAATGATGGGGAACAACT } \\
\text { R: TGCACGTGTATCCCTCAAAA }\end{array}$ & 60 & 500 & 500 \\
\hline
\end{tabular}

${ }^{\mathrm{a}} \mathrm{F}=$ forward primer, $\mathrm{R}=$ reverse primer. 
probably different from that mediated by the dominant genes $O l-1$ and $O l-4$.

\section{DISCUSSION}

\section{$\mathrm{H}_{2} \mathrm{O}_{2}$ and callose accumulation are associated} with HR and papilla formation.

The interaction of barley and barley powdery mildew (Blumeria graminis f. sp. hordei) is a well-investigated pathosystem. Dozens of resistance genes render the plant resistant to different $B$. graminis f. sp. hordei isolates (Schulze-Lefert and Vogel 2000). These genes arrest fungal development at different stages of the interaction: at the penetration stage while the attacked cells stay alive ( $m l o 5)$, at the penetration stage in cells that subsequently undergo a single-cell HR $(M l g)$, or after fungal penetration by subsequent multicell HR (Mla12) (Hückelhoven et al. 2000). Here, we demonstrate by microscopic phenotyping the similarities between some $B$. graminis f. sp. hordei resistance genes in barley and $\mathrm{Ol}$ genes in tomato: papilla-associated resistance response mediated by the recessive genes ol-2 and $m l o$, fast HR-associated resistance governed by the dominant genes $\mathrm{Ol}-4$ (HR at primary haustorium stage) and $M l g$ (HR at primary appressorium stage), and slow HR-associated resistance by the dominant genes of $\mathrm{Ol}-1$ and Mla 12. In barley, papillae are formed in both compatible and incompatible interactions with $B$. graminis f. sp. hordei. Papillae are not penetrated in the resistant genotypes bearing the genes $\mathrm{Mlg}$ and $\mathrm{mlo5}$, while successful penetration happens in the susceptible genotype and in resistance genotypes carrying the Mla12 gene. In tomato, papilla formation is only associated with ol-2-mediated resistance (Fig. 1) (Bai et al. 2005). Like mlo-mediated resistance in barley, ol-2 arrests fungal growth at the penetration stage (before $41 \mathrm{hpi}$ ), as more than $90 \%$ of papillae are not penetrated (Table 1). However, at $65 \mathrm{hpi}$, up to $40 \%$ of papillae in F3-ol-2 can be penetrated by the fungus to form a haustorium, which is not the case in mlo-based resistance in barley (Bai et al. 2005). Although hyphae elongation was observed at 65 hpi after primary haustorium formation, further fungal growth was significantly reduced in F3-ol-2 and fungal mycelium was not visible on the leaves (Bai et al. 2005).

One of the most rapid defense responses following pathogen recognition is the so-called oxidative burst, which results in the production of ROS at the site of attempted invasion and in cells attacked by the pathogen (Grant and Loake 2000). In barley, a superoxide anion $\left(\mathrm{O}_{2}^{-}\right)$burst is seen in compatible cells with successful fungal penetration but not in the HR cells and papillae, while $\mathrm{H}_{2} \mathrm{O}_{2}$ is closely associated with HR and the formation of effective papillae (Hückelhoven and Kogel 1998; Hückelhoven et al. 1999). The generation of ROS was studied during the infection of $O$. neolycopersici on some resistant wild-tomato species (Milckova et al. 2004; Tománková et al. 2006). An intensive production of $\mathrm{H}_{2} \mathrm{O}_{2}$ was found in the leaves of highly resistant $S$. habrochaites LA2128 and moderately resistant $S$. chmielewskii LA2663, compared with a very weak or no $\mathrm{H}_{2} \mathrm{O}_{2}$ signal in highly susceptible $S$. lycopersicum cv. Amateur. In contrast, the production of $\mathrm{O}_{2}^{-}$was observed mostly in leaves of the susceptible cv. Amateur. By using well-defined genetic materials in the present study, we demonstrated that the generation of $\mathrm{H}_{2} \mathrm{O}_{2}$ is strongly associated with both HR and papilla formation and, thus, is involved in powdery mildew resistance mediated by different monogenic $O l$ genes. However, toxic ROS molecules are potentially harmful to plant cells. Therefore, the steadystate level of ROS in cells needs to be tightly regulated, which requires a large gene network. For example, at least 152 genes in Arabidopsis are involved in managing the level of ROS, and expression of the genes in this network respond in a highly specific manner to different biotic and abiotic stress factors (Mittler et al. 2004). In our cDNA-AFLP analysis, TDF are identified (Appendix 1, no. 7, 8 and 13) that show homology to genes involved in the interplay between ROSproducing and ROS-scavenging pathways of cells. Further functional analysis of these candidates will contribute to our understanding of how the different enzymes of the ROS network cooperate during the interaction of tomato with $O$. neolycopersici.

\begin{tabular}{|c|c|c|c|c|c|c|}
\hline Name & $\begin{array}{l}\text { Putative function, roles in } \\
\text { plant-pathogen interaction or }\end{array}$ & $\begin{array}{l}\text { Accession/ } \\
\text { TC No. }\end{array}$ & S-MM & NIL-Ol-1 & F3-ol-2 & NIL-Ol-4 \\
\hline & defense pathway & & ${ }^{\mathrm{a}} \mathrm{P} 13579$ & P13579 & P13579 & P13579 \\
\hline GluB & $\begin{array}{l}\text { Basic } \beta \text {-1,3-glucanase (PR2), } \\
\text { response to JA and ethylene }\end{array}$ & M80608 & $=-000$ & $2+00$ & 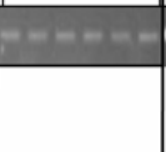 & $5000=0$ \\
\hline PR1 & $\begin{array}{l}\text { PR1, marker gene of SAR, } \\
\text { response to SA, JA and ethylene }\end{array}$ & M69247 & & & & \\
\hline LeROR2 & $\begin{array}{l}\text { Syntaxin-related protein Nt-syr1, } \\
\text { for penetration resistance }\end{array}$ & TC166265 & & & & \\
\hline LeSGT1 & $\begin{array}{l}\text { Ubiquitin ligase-associated } \\
\text { protein, ubiquitination pathway }\end{array}$ & TC162726 & & عصعصد & صعص & - \\
\hline Actin & Constitutively expressed gene & - & & & & \\
\hline
\end{tabular}

Fig. 5. The agarose-gel images displaying reverse transcription-polymerase chain reaction products amplified with primer pairs designed according to sequence of marker genes of different defense signaling pathways. ${ }^{a} \mathrm{P}$ represents the pooled mock-inoculated samples harvested at $1,3,5,7$, and 9 days postinoculation (dpi); inoculated samples are represented by numbers referring to sampling at 1,3,5,7, and 9 dpi; arrows indicate the target transcript derived fragments. 
Callose, a $(1 \rightarrow 3)-\beta$-D-glucan, is synthesized and deposited rapidly at the cell wall upon microbial attack, which has been thought to contribute to a physical barrier that slows or arrests the growth of invading microorganisms. However, it has been recently shown that mutants in the GSL5/PMR4 (glucan synthase-like5/powdery mildew resistance 4) gene exhibit broadspectrum enhanced disease resistance to virulent powdery mildews, indicating that callose may also promote fungal colonization of host plants rather than contribute to disease resistance (Jacobs et al. 2003; Nishimura et al. 2003). In the present study, we show that callose is indeed deposited at the penetration sites in both compatible and incompatible interactions of tomato with $O$. neolycopersici (Figs. 2D and 3E and F), although papilla formation is not obvious in S-MM and in the HR-associated incompatible interactions. The data demonstrate that callose accumulates much faster in the resistant genotypes than in S-MM, suggesting that the timing of callose deposition is relevant for the outcome of resistance or susceptibility in the interaction between tomato and $O$. neolycopersici. Callose accumulation in S-MM at 41 hpi may also indicate that callose plays a positive role in fungal colonization.

Our data showed that the germination rates of $O$. neolycopersici on the resistant genotypes were lower than on S-MM. In principal, leaf surface compounds and morphological features of plants may affect germination rates (Niks and Rubiales 2002). Also, $\mathrm{H}_{2} \mathrm{O}_{2}$ may inhibit spore germination of a number of fungal pathogens (Mehdy 1994). As the NIL used in our study are morphologically S-MM-like, we reasoned that leaf surface may not contribute to the inhibition of spore germination on the resistance genotypes. Whether $\mathrm{H}_{2} \mathrm{O}_{2}$ accumulation plays a role in the low germination ratio in the resistant genotypes needs to be further investigated.

\section{Differences in transcript profiles \\ of resistance responses mediated by $o l-2, \mathrm{Ol}-1$, and $\mathrm{Ol}-4$.}

cDNA-AFLP profiling clarified that $81 \%$ of the up-regulated DE-TDF are common for both compatible and incompatible interactions. These classes of DE-TDF could constitute either basal defense genes (Group A in Table 2 and Appendix 1) or infection-induced genes. All these common DE-TDF are upregulated in both S-MM and NIL-Ol-1, with differences in timing of expression for certain DE-TDF, as previously reported by Li and associates (2006). The similarity between S-MM and NIL-Ol-1 is likely due to the fact that slow HR was involved in the resistance mediated by $\mathrm{Ol}-1$, resulting in a high level of fungal growth (Table 1). Compared with NIL-Ol-1, the differentially expressed transcript profile of NIL-Ol-4 was very different, as more than $70 \%$ of the DE-TDF that were up-regulated in NIL-Ol-1 were not detected in NIL-Ol-4. It is surprising that the DE-TDF profile of NIL-Ol-4 deviated so much from NIL-Ol-1, since both $\mathrm{Ol}-1$ and $\mathrm{Ol}-4$ genes are associated with HR-associated resistance responses. One explanation for this outcome might be that fast HR-associated resistance could employ a different defense pathway compared with that used by slow HRassociated resistance. Another explanation is that the amplitude of transcripts of inoculated NIL-Ol-4 plants was below the detection limit of cDNA-AFLP, owing to the fact that hardly any cells were observed to interact compatibly with $O$. neolycopersici, and thus, the infection-induced genes could not be detected (Fig. 1) (Bai et al. 2005).

In contrast to the differences in transcription profiles between NIL-Ol-1 and NIL-Ol-4, great similarities were observed between NIL-Ol-1 and F3-ol-2. Upon fungal infection, up to $58 \%$ (Fig. 4, Class I and II-b) of the DE-TDF that were upregulated in S-MM and NIL-Ol-1 showed upregulation in F3ol-2. This result is unexpected, as the ol-2-based resistance employs an entirely different mechanism; papillae are formed and HR plays no role. However, about $40 \%$ of the attacked epidermal cells in F3-ol-2 appeared compatible at the cellular level, as demonstrated by fungal haustorium formation at 65 hpi (Fig. 1) (Bai et al. 2005). If such compatible cells express genes induced by infection, then expression of these genes should be detected in F3-ol-2 but at later timepoints compared with S-MM and NIL-Ol-1.

Class-III DE-TDF were up-regulated only in incompatible interactions. They were specific to different resistant interactions (Fig. 4), suggesting that different sets of genes are required for resistances mediated by each $\mathrm{Ol}$-gene. As discussed above, the resistance responses to $\mathrm{O}$. neolycopersici governed by the $\mathrm{Ol}$ genes are very similar to the $B$. graminis f. sp. hordei resistance responses mediated by the barley $M l a, M l g$, and $m l o$ genes, respectively. In barley, Rarl and Rar2 have been identified that are required for the resistance mediated by certain Mla genes but not for Mlg. Rorl and Ror 2 are necessary for the broadspectrum resistance governed by mlo (Freialdenhoven et al. 1994, 1996; Hückelhoven et al. 2001). Therefore, we expect that in the interaction of tomato with $O$. neolycopersici, different genes that are essential for specific $O l$ genes exist and play roles like Rar1, Rar2, Ror1, and Ror2. Sequences of many Class III TDF do not yet provide a lead to their function; we are using virus-induced gene silencing (Liu et al. 2002) to reveal their requirement in different defense responses mediated by the $O l$ genes.

\section{Resistance mechanisms involved in papilla- and HR-associated resistance.}

Certain DE-TDF (Class II-c) and the GluB gene showed nonaltered expression in F3-ol-2 as compared with upregulation in other genotypes, though it cannot be excluded that upregulation occurs in F3-ol-2 at later timepoints not included in our experiment. The fact that the expression of class II-c DE-TDF was not altered in F3-ol-2 compared with upregulation in NIL-Ol-1 and NIL-Ol-4 indicates that the molecular mechanism involved in the papilla-associated resistance in F3ol-2 is different from the HR-associated resistances mediated by $O l-1$ and $O l-4$. This hypothesis is in agreement with the fact that specific TDF showing homology to genes involved in signal transduction and regulation are associated with different $O l$ genes (Fig. 4). For example, TDF M16E35-365 (Appendix 1, no. 29) with homology to phytochrome kinase is specifically up-regulated in NIL-Ol-4, while TDF M19E37-408 and M12E60-245 (Appendix 1, no. 26 and 27) with homology to an elicitor-responsible gene and to DEAD RNA helicase for regulation, respectively, are only up-regulated in F3-ol-2. It has been reported that phytochrome signaling interacts with the SA-perceptive pathway in Arabidopsis and RNA helicaselike proteins serve as early regulators of transcription factors for plant chilling and freezing tolerance (Genound et al. 2002; Gong et al. 2002). Unfortunately, at the present time, most of the TDF are homologous to expressed sequence tags with unknown function. Therefore, it is important to further study the function of the Class III TDF to understand the molecular mechanisms associated with HR- and papilla-associated resistances to $O$. neolycopersici.

Many studies have reported that PR proteins increase much faster in incompatible than in compatible interactions (Lo et al. 1999). This is also the case here, since our data show that GluB and $P R-1$ were up-regulated earlier in NIL-Ol-4 than in S-MM. As $P R-1$ is responsive to the application of JA, ET, or SA in tomato (Van Kan et al. 1995) and GluB is induced by analogs of JA and ET in tomato (Van Kan et al. 1995), the very late upregulation of the $P R-1$ gene and nonaltered expression of the $G l u B$ gene in F3-ol-2 might suggest that the ol-2-mediated resistance 
is independent of JA and ET but also of SA at earlier interaction stages. The induced expression of DE-TDF M12E62-186 (Appendix 1, no. 12) in S-MM and NIL-Ol-1 but later in F3-ol-2 is consistent with this hypothesis, as this TDF is homologous to shikimate dehydrogenase, the enzyme responsible for the synthesis of shikimate, which is a general precursor of the SA biosynthesis pathways (Shah 2003). The absence of upregulation of this TDF in NIL-Ol-4 might indicate noninvolvement of SA in the Ol-4-mediated defense response. In barley, the HR- and papilla-associated $B$. graminis f. sp. hordei resistances, discussed earlier, do not depend on SA accumulation, while $P R$ gene transcripts accumulate upon $B$. graminis f. sp. hordei inoculation, suggesting that $P R$ gene expression is independent of the accumulation of SA (Hückelhoven et al. 1999; VallélianBindschedler et al. 1998). In Arabidopsis, broad-spectrum mildew resistance mediated by $R P W 8$ induces SA-dependent defenses, while the mlo-based resistance against the adapted powdery mildew species does not require SA-, JA-, or ET-mediated signaling (Consonni et al. 2006; Xiao et al. 2001). To study the involvement of SA, JA, and ET pathways in the interaction of tomato and $O$. neolycopersici, the NIL (bearing the genes of $\mathrm{Ol}$ $1, \mathrm{ol}-2$ and $\mathrm{Ol}-4$ ) are being crossed to tomato mutants including NahG, defl, and Never-ripe that are deficient in SA, JA, and ethylene biosyntheses. By testing progenies of these crosses, the involvement of SA, JA, and ET in the resistance mechanisms mediated by the $O l$ genes will be clarified.

In general, our data showed that ROS, callose accumulation, and upregulation of DE-TDF corresponding to certain basal defense genes are associated with the resistances conferred by the dominant and recessive $\mathrm{Ol}$ genes. These results demonstrate the convergence of $\mathrm{R}$ protein-triggered defense and the basal defense signaling as described in the introduction. The different induction of the two PR genes and certain DE-TDF among the resistance genotypes may suggest that immune responses associated with the $o l-2$ gene are different from that with the dominant $\mathrm{Ol}$ genes. Shen and associates (2007) indicated that, in the pathosystem of barley and barley powdery mildew, independent $\mathrm{R}$ protein-triggered immunity responses exist for the Mla-, Mlg-, and mlo-mediated resistances, which might be also the case for the $O l$ gene-mediated resistances. Further functional analysis of the DE-TDF that are specific to different resistant interactions will help the understanding of the $\mathrm{Ol}$ protein-triggered immunity signaling and their crosstalk with PTI.

\section{MATERIALS AND METHODS}

\section{Plant materials.}

Four tomato genotypes were used in this study. S. lycopersicum cv. Moneymaker was used for the compatible interaction. NIL-Ol-1, NIL-O1-4, and F3-ol-2 are resistant lines associated with different mechanisms, HR in both NIL and papilla formation in F3-ol-2 (Bai et al. 2005). The construction and genetic background of the NIL have been described by Bai and associates (2005).

\section{Disease test and sampling.}

The inoculum of Wageningen isolate of $O$. neolycopersici was prepared as described by Bai and associates (2005). All plants were grown in climate cells at Wageningen in The Netherlands, with optimal temperature, photoperiod, and light conditions (20 $\pm 2{ }^{\circ} \mathrm{C}, 16 \mathrm{~h}$ daytime, light intensity $150 \mu \mathrm{mol} / \mathrm{m}^{2} \mathrm{~s}^{-1}$ ).

For the histological study, eight randomly arranged 1month-old plants per line were inoculated by spraying a spore suspension of $3 \times 10^{5}$ conidia per milliliter on the fourth true leaf (expanded) of 1-month-old plants. At timepoints 18, 24, and $41 \mathrm{hpi}$, an entire leaflet and six leaf segments of $1 \times 3 \mathrm{~cm}^{2}$ were collected from the inoculated fourth leaf (two plants per line per timepoint). In addition, two extra leaf segments per plant were sampled at 41 hpi to determine the germination ratio.

For the cDNA-AFLP study, the experimental setup was according to a completely randomized block design with five blocks. Each block contained the four lines with two plants per line. One plant was inoculated by spraying with an $O$. neolycopersici spore suspension of $2 \times 10^{4}$ conidia per milliliter, and the other one was mock-inoculated with water. Onemonth-old plants were inoculated. The second and third true leaves were sampled at $1,3,5,7$, and 9 dpi for all the genotypes and treatments. One plant per block was used per timepoint.

\section{Staining and microscopic observation.}

To monitor fungal growth, three leaf segments per plant per timepoint were stained with chloral hydrate and trypan blue as described by Huang and associates (1998). To observe callose deposition, three leaf segments per plant per timepoint were decolorized in acetic acid/ethanol $(1: 3, \mathrm{vol} / \mathrm{vol})$ and then were stained with aniline blue in $0.07 \mathrm{M} \mathrm{K}_{2} \mathrm{HPO}_{4}$ for UV light observation as published by Heath (1974). Detection of $\mathrm{H}_{2} \mathrm{O}_{2}$ was done by an endogenous peroxidase-dependent in situ histochemical staining procedure using DAB. Leaflets (one per plant per timepoint) were placed in tubes containing a solution of $1 \mathrm{mg}$ of DAB per milliliter for $8 \mathrm{~h}$. Subsequently, three leaf segments per leaflet were sampled and incubated in acetic acid/ethanol (1:3, vol/vol) for at least $30 \mathrm{~min}$. Afterwards, the leaf segments were stained with $0.01 \%$ trypan blue in lactophenol/ethanol (1:3, vol/vol) as described above.

To prevent washing away of spores, the spore germination ratio was determined by staining the two extra leaf segments collected at 41 hpi with trypan blue in lactophenol and ethanol in petri dishes. The leaf segments were put on paper tissue in a petri dish and were kept immobile during the staining procedure.

A spore was considered as germinated if it produced either a germ tube of at least half of the length of the spore or a germ tube with a primary appressorium. An IU was defined as a germinated spore that produced at least a primary appressorium. A total of $20 \mathrm{IU}$ per leaf segment were scored. The number of hyphae, appressoria, and haustoria per IU were recorded, as well as the presence of cell necrosis, papilla formation, $\mathrm{H}_{2} \mathrm{O}_{2}$ production, and callose depositions at the penetration sites and in cells.

\section{cDNA-AFLP and sequence analysis.}

The cDNA-AFLP protocol was as described by Li and associates (2006). Target DE-TDF were excised from polyacrylamide electrophoresis gels using the Odyssey machine (LICOR, Lincoln, NB, U.S.A.), were reamplified with standard AFLP primers $M s e \mathrm{IO0}$ and EcoRI00, and were purified over G50 columns (Amersham Bioscience, Piscataway, NJ, U.S.A.). The PCR products were sequenced directly (Baseclear, Leiden, The Netherlands). The BLAST results were obtained from the TIGR tomato and Arabidopsis TC databases using BLASTN and TBLASTX. The sequenced DE-TDF were, if possible, mapped onto the tomato genome by blasting against the Solanaceae genomics network unigene, and marker databases.

\section{Primer design and RT-PCR.}

The sequences of marker genes of different disease resistance pathways were obtained from websites (TIGR and NCBI databases). Primers (Table 3) were designed using the program Primer 3. The primer sequences of actin were obtained from literature (Ditt et al. 2001). RT-PCR was carried out with the following PCR program: 1 cycle at $94^{\circ} \mathrm{C}$ for $1 \mathrm{~min}$, followed by 30 cycles of $30 \mathrm{~s}$ at $94^{\circ} \mathrm{C}, 30 \mathrm{~s}$ at annealing temperature (Table 3), $60 \mathrm{~s}$ at $72^{\circ} \mathrm{C}$, and a final extension of $7 \mathrm{~min}$ at $72^{\circ} \mathrm{C}$. The PCR products were displayed on $1.2 \%$ agarose gels. 
Appendix 1. The putative functions of the sequenced DE-TDF (differentially expressed transcript derived fragments of different classes, based on the BLAST results against TIGR tomato and Arabidopsis tentative consensus (TC) database (only the DE-TDF with BLAST E value $<5.0 \mathrm{e}-2$ are listed).

\begin{tabular}{|c|c|c|c|c|c|c|}
\hline No. & PC-size ${ }^{a}$ & Expression class $^{\mathbf{b}}$ & E value/ Identity & Group $^{c}$ & Homology annotation ${ }^{d}$ & Reference nos. \\
\hline 1 & M22E61-510 & I & $1.1 \mathrm{e}-34 / 95 \%$ & A & $\begin{array}{l}>\underline{\text { tomato|TC162516 }} \text { similar to UP|Q93WS1 (Q93WS1) } \\
\text { selenium-binding protein }\end{array}$ & 5 \\
\hline 2 & M12E62-196 & I & $1.3 e-17 / 93 \%$ & B & $\begin{array}{l}>\text { tomato|TC162880 homolog to UP|O22402 (O22402) GDP } \\
\text { dissociation inhibitor }\end{array}$ & 7 \\
\hline 3 & M15E71-220 & I & $1.1 \mathrm{e}-27 / 95 \%$ & $\mathrm{C}$ & $>$ >tomato|TC154081 UP|Q43529 (Q43529) Homeobox, & 36 \\
\hline 4 & M13E64-325 & I & $2.1 \mathrm{e}-47 / 97 \%$ & $\mathrm{D}$ & $\begin{array}{l}\text { >tomato|TC161777 homolog to UP|O82529 (O82529) } \\
\text { ribosomal protein L27a }\end{array}$ & \\
\hline 5 & M12E42-265 & II-a & $2.5 \mathrm{e}-18 / 89 \%$ & A & $\begin{array}{l}>\text { tomato|TC162024 similar to UP|C762_SOLME (P37122) } \\
\text { Cytochrome P450 76A2 CYPLXXVIA2) (P-450EG7) }\end{array}$ & 18 \\
\hline 6 & M12E58-290 & II-a & $8.9 \mathrm{e}-44 / 98 \%$ & A & $\begin{array}{l}\text { >tomato|TC153678 similar to UP|CHIC_LYCES (Q05538) } \\
\text { basic 30-kDa endochitinase precursor (PR-2) }\end{array}$ & \\
\hline 7 & M18E41-260 & II-a & $5.3 \mathrm{e}-1 / 82 \%$ & A & $\begin{array}{l}>\text { tomato|TC155487 weakly similar to UP|Q86GL5 (Q86GL5) } \\
\text { Peroxiredoxin 3, }\end{array}$ & 4 \\
\hline 8 & M13E51-460 & II-a & $1.3 \mathrm{e}-71 / 99 \%$ & A & $\begin{array}{l}\text { >tomato|TC162242 homolog to UP|GTX1_SOLTU (P32111) } \\
\text { Probable glutathione } S \text {-transferase }\end{array}$ & 20 \\
\hline 9 & M13E49-150 & II-a & $2 \mathrm{e}-5$ & $\mathrm{~B}$ & $\begin{array}{l}\text { >TC116965 similar to GP }|22093651| \text { dbj|BAC06946. Putative } \\
\text { GTP-binding protein \{ Oryza sativa (japonica cultivar- } \\
\text { group)\}, partial ( } 92 \% \text { ) }\end{array}$ & 30 \\
\hline 10 & M23E55-196 & II-a & $8.4 \mathrm{e}-15 / 94 \%$ & $\mathrm{D}$ & $\begin{array}{l}>\text { tomato|TC153698 homolog to gb|AF036493.1|AF036493 } \\
\text { Tragopogon dubius large subunit 26S ribosomal RNA gene, } \\
\text { partial sequence, partial (80\%) }\end{array}$ & 15 \\
\hline 11 & M21E56-370 & II-a & $6 e-19$ & $\mathrm{H}$ & $\begin{array}{l}>\text { BG123848 weakly similar to GP }|22136960| \text { gb unknown } \\
\text { protein }\{\text { Arabidopsis thaliana }\} \text {, partial }(17 \%)\end{array}$ & \\
\hline 12 & M12E62-186 & II-b & $2.8 \mathrm{e}-19 / 96 \%$ & A & $\begin{array}{l}\text { >tomato|TC161002 weakly similar to UP|Q6PUG0 (Q6PUG0) } \\
\text { 3-dehydroquinate dehydratase/shikimate dehydrogenase } \\
\text { isoform } 2\end{array}$ & 3 \\
\hline 13 & M21E53-455 & II-b & $1.1 e-64 / 99 \%$ & A & $\begin{array}{l}\text { >tomato|TC162242 homolog to UP|GTX1_SOLTU (P32111) } \\
\text { Probable glutathione } S \text {-transferase }\end{array}$ & 28 \\
\hline 14 & M13E64-215 & II-b & $1.5 \mathrm{e}-25 / 100 \%$ & $\mathrm{C}$ & $\begin{array}{l}\text { >tomato|TC167295 similar to UP|ENO_LOLPE (O02654) } \\
\text { Enolase (2-phosphoglycerate dehydratase) }\end{array}$ & \\
\hline 15 & M21E53-310 & II-b & $4.2 \mathrm{e}-4 / 61 \%$ & $\mathrm{C}$ & $>\frac{\text { tomato|TC162485 weakly similar to UP|NUCL_HUMAN }}{\text { (P19338) nucleolin (Protein C23) }}$ & 11 \\
\hline 16 & M15E34-170 & II-b & $8.9 \mathrm{e}-10 / 82 \%$ & $\mathrm{D}$ & $\frac{>\text { arab|BU634848 similar to SP }|\mathrm{O} 59950| \mathrm{RS} 4 \_40 \mathrm{~S} \text { ribosomal }}{\text { protein S4 (S7). [Candida lipolytica] }\{\text { Yarrowia lipolytica }\}}$ & \\
\hline 17 & M16E58-205 & II-b & $1 e-7$ & $\mathrm{D}$ & $\begin{array}{l}\text { >TC117131 homolog to GP }|3808101| \mathrm{emb} \mid \mathrm{CAA} 09935.1 \\
\text { chloroplast protease }\{\text { Capsicum annuит }\} \text {, complete }\end{array}$ & 14 \\
\hline 18 & M12E62-800 & II-c & $4.4 \mathrm{e}-115 / 89 \%$ & $\mathrm{D}$ & >tomato|TC153558 UP|Q39257 (Q39257) ubiquitin & 38 \\
\hline 19 & M16E75-206 & II-c & $2.3 e-18 / 99 \%$ & $\mathrm{H}$ & >tomato|AW737782 & \\
\hline 20 & M19E35-148 & II-c & $5.4 \mathrm{e}-10 / 96 \%$ & $\mathrm{H}$ & $\begin{array}{l}>\text { tomato|TC156146 similar to TIGR_Ath1|At1g15980.1 } \\
\text { 68414.m01917 expressed protein }\end{array}$ & \\
\hline 21 & M19E37-131 & II-c & $5.4 \mathrm{e}-10 / 96 \%$ & $\mathrm{H}$ & $\begin{array}{l}>\text { tomato|TC156146 similar to TIGR_Ath1|At1g15980.1 } \\
\text { 68414.m01917 expressed protein }\end{array}$ & \\
\hline 22 & M19E37-148 & II-c & $5.4 \mathrm{e}-10 / 96 \%$ & $\mathrm{H}$ & $\begin{array}{l}>\text { tomato|TC156146 similar to TIGR_Ath1|At1g15980.1 } \\
\text { 68414.m01917 expressed protein }\end{array}$ & \\
\hline 23 & M14E42-465 & III-a & $1.4 \mathrm{e}-71 / 93 \%$ & $\mathrm{C}$ & $\begin{array}{l}>\text { tomato|TC153824 UP|ENO_LYCES (P26300) Enolase (2- } \\
\text { phosphoglycerate dehydratase) (2-phospho-D-glycerate } \\
\text { hydro-lyase), a bi-function transcription factor }\end{array}$ & 64 \\
\hline 24 & M11E69-195 & III-a & $3.9 e-20 / 80 \%$ & $\mathrm{E}$ & $\begin{array}{l}\text { >tomato|TC116384 homolog to SP|P09114|ILV2_TOBAC } \\
\text { Acetolactate synthase II chloroplast precursor (EC 4.1.3.18) } \\
\text { (Acetohydroxy-acid synthase II), partial (10\%) }\end{array}$ & \\
\hline 25 & M14E72-213 & III-a & $1.0 \mathrm{e}-23 / 97 \%$ & $\mathrm{H}$ & $\begin{array}{l}\text { >tomato|TC156168 similar to TIGR_Ath1|At1g21390.1 } \\
\text { 68414.m02676 expressed protein }\end{array}$ & \\
\hline 26 & M19E37-408 & III-b & $1.1 \mathrm{e}-52 / 98 \%$ & B & $\begin{array}{l}>\text { tomato|TC162602 similar to UP|Q9FXT0 (Q9FXT0) Elicitor } \\
\text { responsible protein(TCIP), partial (43\%) Length }=729\end{array}$ & \\
\hline 27 & M12E60-245 & III-b & $2.2 \mathrm{e}-22 / 76 \%$ & $\mathrm{C}$ & $\begin{array}{l}\text { >At5g08610.1 68418.m01024 DEAD box RNA helicase } \\
\text { (RH26) translation initiation factor kinase }\end{array}$ & \\
\hline 28 & M12E62-620 & III-b & $5.9 \mathrm{e}-55 / 95 \%$ & $\mathrm{E}$ & $\begin{array}{l}\text { >tomato|TC153545 UP|CB2B_LYCES (P07370) Chlorophyll } \\
\text { a-b binding protein 1B, chloroplast precursor (LHCII type I } \\
\text { CAB-1B) (LHCP), }\end{array}$ & \\
\hline 29 & M16E35-365 & III-c & $7.9 \mathrm{e}-06 / 59 \%$ & B & >At1g14280.1 68414.m01693 phytochrome kinase, & \\
\hline 30 & M22E35-520 & IV & $1.3 e-21 / 66 \%)$ & A & $>\underset{\text { multiplication 2B }}{\text { mabC275227 UP|Q8H960 (Q8H960) Tobamovirus }}$ & 61 \\
\hline 31 & M15E71-245 & IV & $1.9 \mathrm{e}-4 / 69 \%$ & B & $\begin{array}{l}\text { >tomato|TC155307 weakly similar to UP|ZOG_PHALU } \\
\text { (Q9ZSK5) Zeatin } O \text {-glucosyltransferase (Trans-zeatin } O \text { - } \\
\text { beta-D-glucosyltransferase) }\end{array}$ & \\
\hline
\end{tabular}

\footnotetext{
a Primer combination and fragment size are listed.

${ }^{\mathrm{b}}$ Classes in this Table refer to expression classes presented in Figure 4.

${ }^{c}$ The functional groups are described in Table 2.

${ }^{\mathrm{d}}$ Homologies are the BLASTN results against TIGR tomato/Arabidopsis TC database.

${ }^{\mathrm{e}}$ Reference numbers by Li et al. 2006.
} 
Appendix 1. Continued from previous page.

\begin{tabular}{|c|c|c|c|c|c|c|}
\hline No. & PC-size ${ }^{a}$ & Expression class $^{b}$ & E value/ Identity & Group $^{c}$ & Homology annotation ${ }^{d}$ & Reference nos. \\
\hline 32 & M16E75-135 & IV & $5.9 \mathrm{e}-08 / 96 \%$ & $\mathrm{~B}$ & $\begin{array}{l}\text { >tomato|TC154636 weakly similar to } \\
\text { TIGR_Ath1|At1g56720.1 68414.m06523 protein kinase } \\
\text { family protein contains protein kinase domain, Pfam:PF00069 }\end{array}$ & \\
\hline 33 & M13E64-170 & IV & $5.1 \mathrm{e}-05 / 70 \%$ & $\mathrm{H}$ & $\begin{array}{l}>\text { dbj|BAB } 11508.1 \text { unnamed protein product }[\text { Arabidopsis } \\
\text { thaliana }]\end{array}$ & \\
\hline 34 & M15E31-198 & IV & $6.8 \mathrm{e}-22 / 94 \%$ & $\mathrm{H}$ & >tomato|TC163631 homolog to expressed protein & \\
\hline 35 & M16E75-175 & IV & $1.1 \mathrm{e}-06 / 72 \%$ & $\mathrm{H}$ & >tomato|BF050774 & \\
\hline 36 & M18E41-220 & IV & $2.8 \mathrm{e}-34 / 95 \%$ & $\mathrm{H}$ & $\begin{array}{l}\text { >tomato|TC159169 similar to TIGR_Ath1|At1g73060.1 } \\
\text { 68414.m08448 expressed protein, partial (66\%). In silico } \\
\text { mapping: TG231 }(8.6 \mathrm{~cm} \text {, near GP79-a marker linked to } \\
\text { Ol-4) (Bai et al. } 2005)\end{array}$ & \\
\hline
\end{tabular}

\section{ACKNOWLEDGMENTS}

We thank B. Brandwacht for his assistance in protein analysis and S. van Heusden and R. Niks for valuable comments. This work was supported partly by the Dutch Technology Foundation (STW, grant number WBI 4835) and Dutch breeding companies, partly by the Joint Ph.D. program between Wageningen University and Chinese Academy of Agricultura Sciences and partly by grants to $\mathrm{C}$. Li from Wageningen University's Laboratory of Plant Breeding, the International Foundation for Science, and the opening Key Laboratory of Vegetable Genetics and Physiology of the Chinese Ministry of Agriculture.

\section{LITERATURE CITED}

Bai, Y., van der Hulst, R., Bonnema, G., Marcel, T. C., Meijer-Dekens, F., Niks, R., and Lindhout, P. 2005. Tomato defense to Oidium neolycopersici: Dominant $\mathrm{Ol}$ genes confer isolate-dependent resistance via a different mechanism than recessive ol-2. Mol. Plant-Microbe Interact. 18:354-362.

Bai, Y., Van der Hulst, R., Huang, C. C., Wei, L., Stam, P., and Lindhout, P. 2004. Mapping Ol-4, a gene conferring resistance to Oidium neolycopersici and originating from Lycopersicon peruvianum LA2172, requires multi-allelic single locus markers. Theor. Appl. Genet. 109:1215-1223.

Chisholm, S. T., Coaker, G., Day, B., and Staskawicz, B. J. 2006. Hostmicrobe interactions: Shaping the evolution of the plant immune response. Cell 124:803-814.

Collins, N. C., Thordal-Christensen, H., Lipka, V., Bau, S., Kombrink, E., Qiu, J. L., Hückelhoven, R., Stein, M., Freialdenhoven, A., Somerville, S. C., and Schulze-Lefert, P. 2003, SNARE-protein-mediated disease resistance at the plant cell wall. Nature 425:973-977.

Consonni, C., Humphry, M. E., Hartmann, H. A., Livaja, M., Durner, J. Westphal, L., Vegel, J., Lipka, V., Kemmerling, B., Schulza-Lefert, P., Somerville, S. C., and Panstruga, R. 2006. Conserved requirement for a plant host cell protein in powdery mildew pathogenesis. Nature Genetics 38:716-720.

Ditt, R. F., Nester, E. W., and Comai, L. 2001. Plant gene expression response to Agrobacterium tumefaciens. Proc. Natl. Acad. Sci. U.S.A. 98:10954-10959.

Flor, H. H. 1971. Current status of the gene-for-gene concept. Annu. Rev. Phytopathol. 9:275-296.

Freialdenhoven, A., Scherag, B., Hollricher, K., Collinge, D. B., ThordalChristensen, H., and Schulze-Lefert P. 1994. Nar-1 and Nar-2, two loci required for Mla12-specified race-specific resistance to powdery mildew in barley. Plant Cell 6:983-984

Freialdenhoven, A., Peterhansel C., Kurth J., Kreuzaler F., and SchulzeLefert P. 1996. Identification of genes required for the function of nonrace-specific mlo resistance to powdery mildew in barley. Plant Cell 8:5-14.

Genound, T., Buchala, A., Chua, N.-H., and Métraux J-P. 2002. Phytochrome signaling modulates the SA-perceptive pathway in Arabidopsis. Plant J. 31:87-95.

Gong, Z. Lee, H., Xiong, L., Jagendrof, A., Stevenson, B., and Zhu, J.-K. 2002 RNA helicase-like protein as an early regulator of transcription factor for plant chilling and freezing tolerance. Proc. Natl. Acad. Sci. U.S.A. 99:11507-11512.

Grant, J. J., and Loake, G. J. 2000. Role of reactive oxygen intermediates and cognate redox signaling in disease resistance. Plant Physiol. 124:21-29.

Heath, M. C., 1974. Light and electron microscope studies of the interactions of host and non-host plants with cowpea rust-Uromyces phaseoli var. vignae. Physiol. Plant Pathol. 4:403-414.

Huang, C. C., Groot, T., Meijer-Dekens, F., Niks, R. E., and Lindhout, P.
1998. The resistance to powdery mildew (Oidium lycopersici) in Lycopersicon species is mainly associated with hypersensitive responses. Eur. J. Plant Pathol. 104:399-407.

Hückelhoven, R., and Kogel, K.-H. 1998 Tissue-specific superoxide generation at interaction sites in resistant and susceptible near-isogenic barley lines attacked by the powdery mildew fungus (Erysiphe graminis $\mathrm{f}$. sp. hordei) Mol. Plant-Microbe Interact. 11:292-300.

Hückelhoven, R. Foder J., Preis, C., and Kogel, K. H. 1999. Hypersensitive cell death and papilla formation in barley attacked by the powdery mildew fungus are associated with $\mathrm{H}_{2} \mathrm{O}_{2}$ but not with salicylic acid accumulation. Plant Physiol. 119:1251-1260.

Hückelhoven, R., Trujillo M., and Kogel, K. H. 2000. Mutation in Rorl and Ror 2 genes cause modification of hydrogen peroxide accumulation in $m l o$-barley under attack from the powdery mildew fungus. Mol. Plant Pathol. 1:287-292.

Hückelhoven, R., Dechert C., Trujillo M., and Kogel K. H. 2001. Differential expression of putative cell death regulator genes in near-isogenic, resistant and susceptible barley lines during interaction with the powdery mildew fungus. Plant Mol. Biol. 47:739-748.

Jacobs, A. K., Lipka, V., Burton, R. A., Panstruga, R., Strizhov, N., Schulze-Lefert, P., and Fincher, G. B. 2003. An Arabidopsis thaliana callose synthase,GSL5, is required for wound and papillary callose formation. Plant Cell 15:2503-2513.

Lamb, C., and Dixon, R. A. 1997. The oxidative burst in plant disease resistance. Ann. Rev. Plant Physiol. Plant Mol. Biol. 48:251-275.

Li, C., Bai, Y., Jacobsen, E.., Visser, R., Lindhout, P., and Bonnema, G. 2006. Tomato defense to the powdery mildew fungus: Differences in expression of genes in susceptible, monogenic- and polygenic resistance responses are mainly in timing. Plant Mol. Biol. 62:127-140.

Liu, Y., Schiff, M., and Dinesh-Kumar, S. P. 2002. Virus-induced gene silencing in tomato. Plant J. 31:777-786.

Lo, S.-C. C., Hipskind, J. D., and Nicholson, R. L. 1999 cDNA cloning of a sorghum pathogenesis-related protein (PR-10) and differential expression of defense-related genes following inoculation with Cochiobolus heterostrophus or Colletotrichum sublineolum. Mol. Plant-Microbe Interact. 12:479-489.

Milckova, K., Luhova, L., Lebeda, A., Mieslerova, B., and Pec, P. 2004 Reactive oxygen species generation and peroxidase activity during Oidium neolycopersici infection on Lycopersicon species. Plant Physiol. Biochem. 42:753-761.

Mittler, R., Vanderauwera, S., Golley, M., and Van Breusegem, F. 2004 Reactive oxygen gene network of plants. Trends Plant Sci. 9:490-498.

Mehdy, M. C. 1994. Active oxygen species in plant defense against pathogens. Plant Physiol. 105:467-472.

Muskett, P., and Parker, J. 2003. Role of SGT1 in the regulation of plant $R$ gene signaling. Microbes Infect. 5:969-976.

Niks, R. E., and Rubiales, D. 2002. Potentially durable resistance mechanisms in plants to specialised fungal pathogens. Euphytica 124:201216.

Nishimura, M. T., Stein, M., Hou, B.H., Vogel, J. P., Edwards, H., and Somerville, S. C. 2003. Loss of a callose synthase results in salicylic acid-dependent disease resistance. Science 301:969-972.

Nurnberger, T., Brunner, F., Kemmerling, B., and Piater L. 2004. Innate immunity in plants and animals: Striking similarities and obvious differences. Immunol Rev. 198:249-266.

Nurnberger, T., and Kemmerling, B. 2006. Receptor protein kinases-pattern recognition receptors in plant immunity. Trends Plant Sci. 11:519-522.

Ricciardi, L., Lotti, C., Pavan, S., Bai, Y., Lindhout, P., De Giovanni, C. 2007. Further isolation of AFLP and LMS markers for the mapping of the $\mathrm{Ol}-2$ locus related to powdery mildew (Oidium neolycopersici) resistance in tomato (Solanum lycopersicum L.). Plant Sci. 72:746-755.

Schulze-Lefert, P., and Vogel, J. 2000. Closing the ranks attack by powdery mildew. Trends Plant Sci. 5:343-348. 
Shah, J. 2003. The salicylic acid loop in plant defense. Curr. Opin. Plant Biol. 6:365-371.

Shen, Q. H., Saijo, Y., Mauch, S., Biskup, C., Bieri, S., Keller, B., Seki, H., Ulker, B., Somssich, I. E., Schulze-Lefert, P. 2007. Nuclear activity of MLA immune receptors links isolate-specific and basal disease-resistance responses. Science 315:1098-1102.

Smart, C. D, Myers, K. L., Restrepo, S., Martin, G. B., and Fry, W. E. 2003. Partial resistance of tomato to Phytophthora infestans is not dependent upon ethylene, jasmonic acid, or salicylic acid signaling pathways. Mol. Plant-Microbe Interact. 16:141-148.

Tao, Y., Xie, Z., Chen, W., Glazebrook, J., Chang, H. S., Han, B., Zhu, T., Zou, G., and Katagiri, F. 2003. Quantitative nature of Arabidopsis responses during compatible and incompatible interactions with the bacterial pathogen Pseudomonas syringae. Plant Cell 15:317-330.

Tománková, K., Luhová, L., Petrivalsky, M., Pec, P., Lebeda, A. 2006. Biochemical aspects of reactive oxygen species formation in the interaction between Lycopersicon spp. and Oidium neolycopersici. Physiol. Mol. Plant Pathol. 68:22-32.
Vallélian-Bindschedler, L., Métraux, J. P., and Schweizer, P. 1998. Salicylic acid accumulation in barley is pathogen specific but not required for defense-gene activation. Mol. Plant-Microbe Interact. 11:702-705.

Van Kan, J. A., Cozijnsen, T., Danhash, N., and De Wit, P. J. 1995. Induction of tomato stress protein mRNAs by ethephon, 2,6-dichloroisonicotinic acid and salicylate. Plant. Mol. Biol. 27:1205-1213.

Xiao, S., Ellwood S., Calis O., Patrick E., Li. T., Coleman M., and Turner J. G. 2001. Broad-spectrum mildew resistance in Arabidopsis thaliana mediated by $R P W 8$. Science 291:118-120.

\section{AUTHOR-RECOMMENDED INTERNET RESOURCES}

TIGR tomato/ Arabidopsis TC databases: www.tigr.org/tdb/tgi/plant.shtml Solanaceae genomics network (SGN) unigene and marker databases: www.sgn.cornell.edu/)

Primer 3 website: frodo.wi.mit.edu 